\title{
Analysis of low-energy and high-frequency femtosecond laser for the construction of deep anterior donor corneal lamellae
}

\author{
Laser de femtossegundo de baixa energia e alta frequência na \\ confecção de lamelas corneanas doadoras
}

Gustavo Victor ${ }^{1}$, Walton Nosé2 ${ }^{2}$ Sidney Julio de Faria e Sousa ${ }^{3}$, Roberto Pineda ${ }^{4}$, Milton Ruiz Alves ${ }^{1}$

\begin{abstract}
Purpose: To evaluate the efficacy and reliability of a low-energy femtosecond laser with a high repetition rate for construction of deep anterior donor corneal lamellae. Methods: This was a prospective laboratory investigation. Twenty-five human corneal buttons were femtosecond laser cut to create thick anterior lamellae (diameter, $10 \mathrm{~mm}$; thickness, $500 \mu \mathrm{m}$ ). The laser cuts were made using an LDV ${ }^{\circledR}$ femtosecond laser in a Ziemer ${ }^{\oplus}$ anterior chamber. To obtain a better edge, the lamellae were trephined with an $8 m m$ trephine (Katena $\left.{ }^{\circledR}\right)$. The central corneal thickness and the anterior lamellae were measured using a Mitutoyo ${ }^{\varpi}$ thickness gauge with an accuracy of $0.001 \mathrm{~mm}$. Results: The central thickness of the 25 corneas ranged from 500 to $705 \mu \mathrm{m}$ (mean, $584 \pm 51 \mu \mathrm{m}$ ). The thickness of the anterior lamellae ranged from 420 to $480 \mu \mathrm{m}$ (mean, $455 \pm 12.7 \mu \mathrm{m}$ ). The anterior lamellae diameters were $7.90 \pm 0.1 \mathrm{~mm}$, and all laser cuts were round. The lamellar interfaces appeared regular by surgical microscopy. There were no cases of inter-lamellar adhesion. Conclusion: The $L D V^{\circledR}$ femtosecond laser appears to be a safe and reliable instrument for cutting deep anterior lamellae from donor corneoscleral buttons. Minimal variation in donor lamellar depth with the laser will be useful for creating donor corneal tissue for deeper anterior lamellar keratoplasty or endothelial keratoplasty surgery or both from a single donor cornea.
\end{abstract}

Keywords: Cornea; Corneal transplantation; Corneal pachymetry; Endothelium; Lasers

\section{RESUMO}

Objetivo: Avaliar a eficácia e segurança de um laser de femtossegundo de baixa energia e alta taxa de repetição para confecção de lamelas corneanas doadoras anteriores profundas. Métodos: Este é um estudo prospectivo de investigação laboratorial. Vinte e cinco botões corneanos foram cortados com laser de femtossegundo para criar lamelas corneanas doadoras anteriores profundas (diâmetro, $10 \mathrm{~mm}$; espessura, $500 \mu \mathrm{m})$. O corte a laser foi realizado com femtosecond laser LDV ${ }^{\circledR}$ na câmara anterior artificial da Ziemer ${ }^{\circledR}$. Para obter-se uma melhor borda, as lamelas foram trepanadas com um trépano de $8 \mathrm{~mm}$ da Katena ${ }^{\circledR}$. A paquimetria corneana central e as lamelas anteriores foram aferidas utilizando o paquímetro Mitutoyo $^{\circledast}$, com acurácia de $0.001 \mathrm{~mm}$. Resultados: A paquimetria central das 25 córneas variou de 500 a $705 \mu \mathrm{m}$ (média de $584 \pm 51 \mu \mathrm{m}$ ). A espessura das lamelas anteriores variou de 420 a $480 \mu \mathrm{m}$ (media de $455 \pm 12.7 \mu \mathrm{m}$ ). O diâmetro das lamelas corneanas doadoras foi $7.90 \pm 0,1 \mathrm{~mm}$, sendo todos os cortes redondos. As interfaces lamelares apresentaram-se regular ao microscópio cirúrgico. Não houve casos de adesão interlamelar. Conclusão: O laser de femtossegundo LDV ${ }^{\circledR}$ mostrou-se seguro e eficaz para confeccionar lamelas corneanas doadoras a partir de botões córneo-esclerais. Mínima variação na espessura das lamelas doadoras confeccionadas com o laser será útil para criação de tecidos corneanos doadores para ceratoplastia lamelar anterior profunda ou ceratoplastia endoteliais, ou ambas, a partir de uma só córnea.

Descritores: Córnea; Transplante de córnea; Paquimetria corneana; Lasers; Endotélio

\footnotetext{
${ }^{1}$ Department of Ophthalmology, Universidade de São Paulo, São Paulo, SP, Brazil;

2 Department of Ophthalmology, Universidade Federal de São Paulo, São Paulo, SP, Brazil;

${ }^{3}$ Department of Ophthalmology, Universidade de São Paulo, Ribeirão Preto, Ribeirão Preto, SP, Brazil;

${ }^{4}$ Department of Ophthalmology, Harvard Medical School, Boston, MA. EUA.
}

This study was support by the Foundation for Research Support of the State of Sao Paulo (FAPESP), www.fapesp.br (acknowledgment). The ethics committee of Universidade de São Paulo School of Medicine approved this prospective and laboratory investigation (study $\mathrm{n}^{\circ} 242 / 11$, approved on 06/22/2011)

The authors declare no conflicts of interest 


\section{INTRODUCTION}

I mprovements in instrumentation and surgical techniques have restored interest in deep lamellar transplantation and endothelial keratoplasty ${ }^{(1)}$. Important elements in this progress have been the use of an artificial anterior chamber ${ }^{(2-5)}$, automated microkeratome ${ }^{(6-11)}$, and both in combination $^{(2-5,12)}$. This was an important technical advance, since cutting irregularities have been considered a major impediment to the visual outcome of lamellar transplantation ${ }^{(10,11)}$. However, one disadvantage of mechanical microkeratomes is the unpredictable depth of cut $^{t^{(13)}}$. This is a major consideration in transplantations where the endothelium is accompanied by a thin layer of the posterior stroma, as in Descemet stripping automated endothelial keratoplasty (DSAEK). The thickness of the posterior layer is ultimately determined by the thickness of the anterior layer, cut by the microkeratome.

If the principal reason for microkeratome depth cut variability is the result of interactions between the corneal substance and mechanical characteristics of the cutting blade (sharpness, inclination, distance from applanation platform, and velocity), the ability to alter this variance are small. Hence, the consideration of the femtosecond laser keratome. This laser delivers pulses of infrared radiation into the tissue while the pulse energy and interval varies with the brand. The tissue is ablated and cleaved with minimal heating, leaving in place parallel rows of microcavities through the process of photodisruption. These cavities define the plane of cleavage and the ensuing cut is thus more accurate, homogeneous, and replicable than a mechanical cut ${ }^{(14-17)}$.

Femtosecond lasers are divided into two groups: those with high energy and low frequency firing (ex. IntraLase ${ }^{\circledR}$, Abbott Medical Optics, Illinois, USA and Perfect Vision ${ }^{\circledR}$, Bausch\&Lomb, München, Germany), and those with low energy and high frequency of firing $\left(\mathrm{LDV}^{\circledR}{ }^{\circledR} \mathrm{Ziemer}^{\circledR}\right.$ Ophthalmic System AG, Port, Switzerland and Visumax ${ }^{\circledR}$, Carl Zeiss Meditec AG, Berlin, Germany) $)^{(14-19)}$. This second group of femtosecond lasers tends to make smoother, more homogeneous, and replicable cuts than the first group due to increased firing rate and the reduced size of cavitation ${ }^{(14-16)}$. They also tend to cause less inflammation and cellular necrosis due to the lower energy delivered ${ }^{(14-19)}$. Therefore, theoretically, they are the best alternative to mechanical microkeratomes. The objective of this study was to evaluate the efficacy and reliability of a low energy-high repetition rate femtosecond laser keratome in the construction of deep anterior corneal lamellae.

\section{Materials and methods}

The ethics committee of Universidade de São Paulo, School of Medicine approved this prospective and laboratory investigation. Twenty-five human corneal buttons were cut to produce deep anterior lamellae. The corneal tissue was procured from eyes having failed eye-bank serological tests. The anterior lamellae parameters were $10 \mathrm{~mm}$ in diameter and $500 \mu \mathrm{m}$ in thickness. The cuts were carried out using an $\mathrm{LDV}^{\circledR}$ femtosecond laser (classic model). The

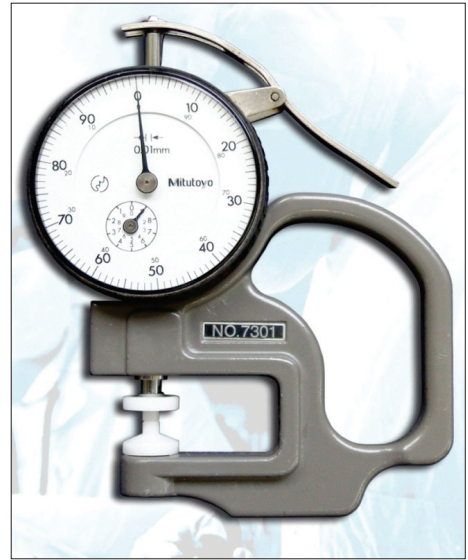

Figure 1:

Mitutoyo $^{\circledR}$

(Mitutoyo ${ }^{\circledR}$, São

Paulo, Brazil)

2110S-10 thickness

gauge, with an

accuracy of

$0.001 \mathrm{~mm}$

pulse frequency of this laser operates in the megahertz range with high-aperture optics, a time exposure per pulse of 200300 femtoseconds, and a spot diameter of $2 \mu \mathrm{m}$. The shots were overlapped to avoid leaving areas without treatment. The energy per pulse was $30 \mathrm{~nJ}^{(14,15,20)}$. The time of construction for each anterior lamellae was approximately 50 seconds. All surgeries were performed at the Eye Clinic Day Hospital, São Paulo, SP, Brazil.

To construct the deep anterior corneal lamellae with the femtosecond laser, the corneas were first attached to the Ziemer ${ }^{\circledR}$ anterior chamber and then flattened using the head of the keratome. After completion of the laser treatment, the corneas were manually trephined from the endothelial side using an $8 \mathrm{~mm}$ trephine blade (Katena ${ }^{\circledR}$ Products, Denville, NJ, USA). Next, the anterior and posterior lamellae were separated by holding the edge of the posterior cornea lamella with forceps and gently sliding the anterior corneal lamella by using the tip of a Meroce ${ }^{\circledR}$ (Medtronic ${ }^{\circledR}$, Connecticut, USA) sponge.

The central corneal thickness and the anterior lamellae were measured with a mechanical thickness gauge with accuracy of $0.001 \mathrm{~mm}$ using a 2110S-10 Mitutoyo ${ }^{\circledR}$ (Mitutoyo®, São Paulo, Brazil) (figure 1). Each measurement was determined from the average of three readings. The diameter of each lamella was measured with a strabismus caliper. The features of the lamellar interface were examined under a surgical microscope. Differences between the observed and expected measurements were analyzed using the Bland-Altman method ${ }^{(21)}$.

The ethics committee of Universidade de São Paulo School of Medicine approved this prospective and laboratory investigation (study $\mathrm{n}^{\circ}$ 242/11, approved on 06/22/2011).

\section{RESULTS}

The central thickness of the twenty-five whole corneas ranged from 500 to $705 \mu \mathrm{m}$ (mean, $584 \pm 51 \mu \mathrm{m}$ ), while the thickness of the anterior lamellae ranged from 420 to $480 \mu \mathrm{m}$ (mean, $455 \pm 12.7 \mu \mathrm{m})$. For each lamella that was cut, differences in central thickness between the observed and expected values were noted. The distribution of these differences is shown in table 1 and figure 2 .

Table 1

\section{Analysis of the difference between observed and expected anterior lamella thickness obtained from an LDV ${ }^{\circledR}$ femtosecond laser adjusted to cuts $500 \mu \mathrm{m}$ in depth}

\begin{tabular}{cccccccccc}
\hline $\mathbf{n}$ & Range & $\mathbf{S}$ & $\mathbf{S E}$ & $\bar{d}$ & $\mathbf{9 5 \%}$ CI $\bar{d}$ & LLA $*$ & $\mathbf{9 5 \%}$ CI LLA & ULA** & 95\% CI ULA \\
\hline 25 & -20 to -70 & 12.70 & 2.54 & -45 & -50 to -40 & -71 & -77 to -65 & -19 & -24 to -13 \\
\hline
\end{tabular}

CI: confidence interval; SE: standard error of the mean $\bar{d} ;(*)$ lower limit of agreement; $(* *)$ upper limit of agreement 

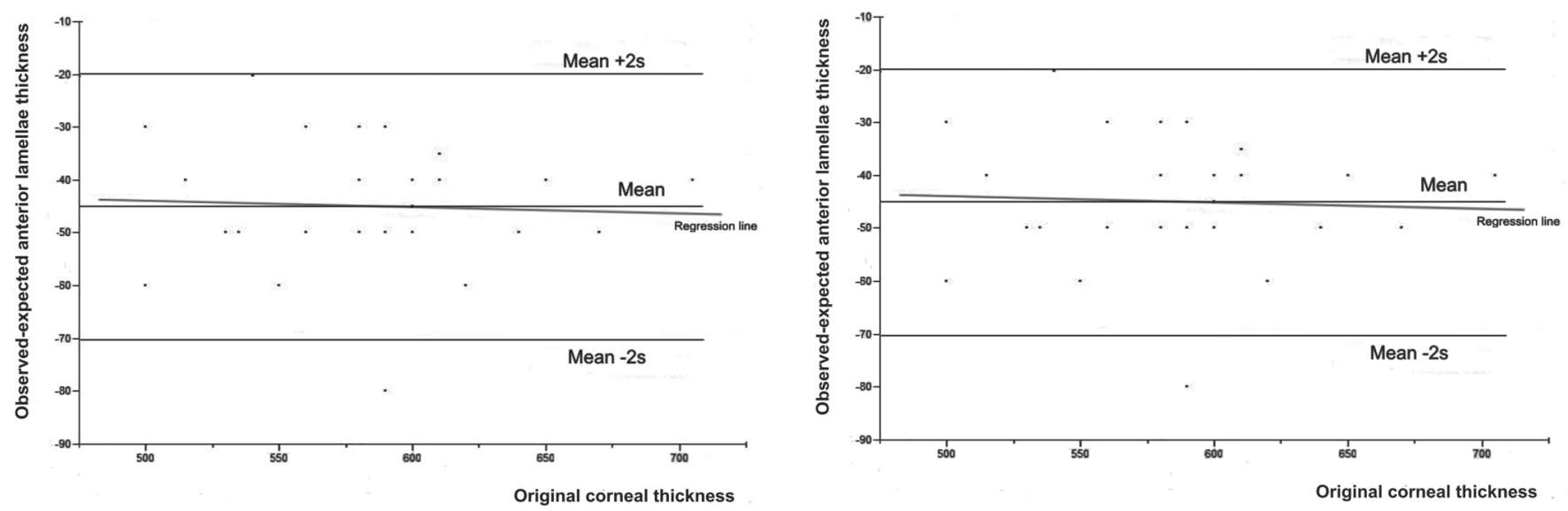

Figure 2: Differences between the observed and expected thickness of the anterior lamellae cut by the LDV ${ }^{\circledR}$ femtosecond laser

Since the differences between the observed and expected lamellae thickness were normally distributed (Shapiro-Wilk Wtest; $\mathrm{Prob}<\mathrm{W}=0.1280), 95 \%$ of them were within two standard deviations (s) of the mean $(\bar{d})$. In figure $1,(\bar{d})+2 \mathrm{~s}$ is the upper limit of agreement while $(\vec{d})-2 \mathrm{~s}$ is the lower limit of agreement. figure 1 also shows a linear regression of these data. The fact that this regression line is almost parallel to the $\mathrm{x}$-axis suggests that the differences were not influenced by the magnitude of corneal thickness $\left(r^{2}=0.002658, \quad\right.$ Prob $\left.>F=0.8067\right)$. This qualifies $(d)$ as a consistent bias that can be neutralized by adjustments to the cutting depth of the instrument. Provided this is done, the remaining differences represent the random error of the method which is about $\pm 2 \mathrm{~s}$.

Regarding the diameter of the lamellae, there were no discrepancies between the observed and expected measurements. All cuts were round, with 7,90 $\pm 0,1 \mathrm{~mm}$ diameter. The lamellar interfaces appeared regular by surgical microscopy. There were no cases of interlamellar adhesion. Figure 3 shows corneal lamellae separation.

\section{Discussion}

Historically, full-thickness penetrating keratoplasty has been the mainstay of therapy to address most forms of stromal and endothelial corneal pathology. However, over the past decade, there has been significant progress in performing site-specific corneal surgery such as endothelial keratoplasty and anterior lamellar keratoplasty. Interest in refining these procedures and improving surgical techniques has ensued. The application of femtosecond laser in these procedures is being explored ${ }^{(22,23)}$. This study evaluated the

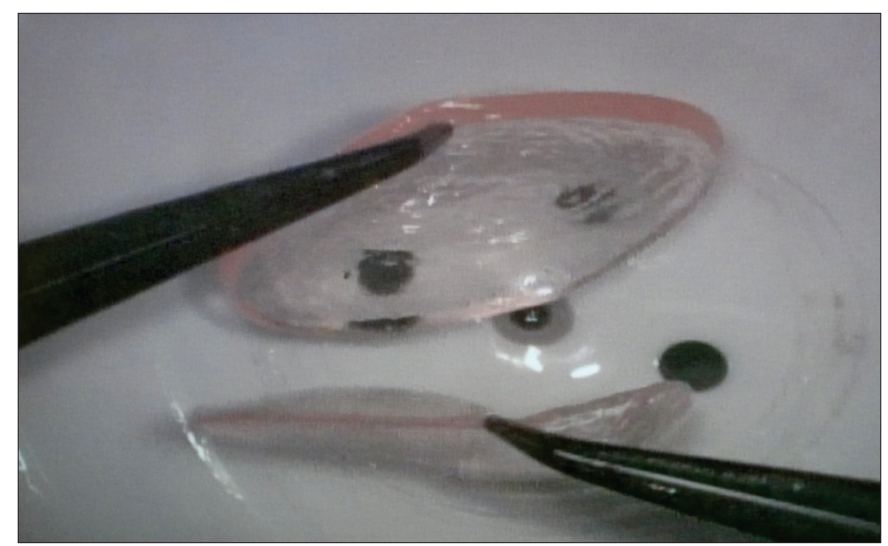

Figure 3: Manual separation of the anterior (thicker) and posterior lamellae (thinner) after cut use of the the $\mathrm{LDV}^{\circledR}$ femtosecond laser for constructing deep anterior lamellae from donor corneoscleral buttons.

Several points should be highlighted in this study. Mechanical rather than ultrasound pachymetry was used in this study. Mitutoyo ${ }^{\circledR}$ micrometer measurements was comparable with Sonogage ${ }^{\circledR}$ ultrasonic pachymeter ${ }^{(24)}$, the only ultrasonic pachymeter capable of measuring epithelial thickness beyond total cornea thickness, then it can improved the accuracy of the measurements.

Using the $\mathrm{LDV}^{\circledR}$ femtosecond laser, a deep cut generates a thick anterior lamella and a thin posterior lamella. In our experience, using available resources of ultrasonic pachymetry for corneal buttons leads to poor performance when the lamellae are less than $150 \mu \mathrm{m}$ thick and has, frequently, more than $10 \mu \mathrm{m}$ of standard deviation. For this reason, all measurements were done on the anterior lamellae and whole corneas. Usually, the thickness of the posterior lamella is obtained by subtracting the former from the latter. The drawback to this approach is that the value of the posterior lamella is simultaneously corrupted by the measurement errors for the whole cornea and anterior lamella. Hence, the use of posterior lamellar thickness to assess the performance of keratomes is problematic, even if actually measured with an ultrasonic pachymeter. This is because current ultrasonic pachymeters are not well-suited for measuring thin lamellae, and, even more importantly, because the total error would always be the sum of the errors generated by two components: the whole cornea and the lamella. This is probably why the literature does not show good predictability for the residual stromal bed, based on preoperative measurements ${ }^{(22,23)}$. To work appropriately with the least variability, the cut depth would have to be set from the endothelial side.

In a study ${ }^{(25)}$ comparing manual microkeratome (Moria ${ }^{\circledR}$ ALTK) versus a femtosecond laser (Intralase ${ }^{\circledR}$ ) to create a precut donnor lamellae, the femtosecond laser was more accurate than microkeratome. Programmed to cut $400 \mu \mathrm{m}$ donnor lamellae, it cut $400 \pm 41 \mu \mathrm{m}$, while the microkeratome was programmed to cut $350 \mu \mathrm{m}$, and did $446 \pm 25 \mu \mathrm{m}$. But were 8 eyes in each group. Other study(26) made the same comparison (same equipament than study(25) with programming donor lamella thickness of $350 \mu \mathrm{m}$. The microkeratome group cut $361 \pm 68 \mu \mathrm{m}$, and the femtosecond laser group did $324 \pm 112 \mu \mathrm{m}$. But, were 5 eyes in each group. Both studies use US pachymetry. The present study shows lower standard deviation than those.

In our sample, about $95 \%$ of the measurements of the anterior lamellae were 71 to $19 \mu \mathrm{m}$ less than expected. The mean difference (d) was $-45 \mu \mathrm{m}$. There are three reasons why this femtosecond mean error (bias) was $-45 \mu \mathrm{m}: 1$ ) because of pachymetric errors, 2) because a safety margin of the company, or 3) combination of both. 
The safety margin is a systematic error to the effective value of cut to be less than the programmed value, in order to increase the safety limit of cutting depth. If the average of effective depth of cut of the femtosecond laser coincide with the average programmed value, surely half the normal random error would be greater than it, and may exceed the safety limit, in borderline cases. So, in planning the thickness of the residual bed for DSAEK, the surgeon has to consider four variables: the thickness of the whole cornea, the error in the corneal measurement, the thickness of the anterior lamella, and the error in its measurement. At present this is not an easy task, mostly due to the lack of reliable ultrasonic pachymetry for corneal lamellae.

The problem with the above reasoning is that it may apply only to the present sample. A second sample would give a different mean and different limit of agreement. The important question is how these differences would look for the general population. That is where the confidence intervals of the mean and of the upper and lower limits of agreement are helpful (table 1). The logic of the confidence intervals for the limits of agreement is exactly the same as for the mean. The only difference is that all possible combinations of the upper and lower limits should be considered to construct the agreement intervals. For example, in the worst-case scenario, the difference between the observed and expected anterior lamellae thicknesses would range from -77 to $-13 \mu \mathrm{m}$.

At least theoretically, the interactions between the corneal substance and laser beam should be significantly smaller than that expected for the metal blade of a mechanical keratome. It is conceivable that most cutting errors are in reality errors of pachymetry. If this is true, the accuracy of this method could be greatly improved by upgrading the technology of pachymetry.

In summary, the LDV $^{\circledR}$ femtosecond laser seems to be a safe and reliable instrument for constructing deep anterior lamellae from donor corneoscleral buttons.

\section{Acknowledgment}

This study was support by the Fundação de Amparo 'a Pesquisa do Estado de São Paulo - FAPESP - São Paulo (SP), Brazil, process number 2011/14699-0.

\section{RefERENCES}

1. Reinhart WJ, Musch DC, Jacobs DS, Lee WB, Kaufman SC, Shtein RM. Deep anterior lamellar keratoplasty as an alternative to penetrating keratoplasty a report by the american academy of ophthalmology. Ophthalmology. 2011;118(1):209-18. Review.

2. Behrens A, Dolorico AM, Kara DT, Novick LH, McDonnell PJ, Chao LC, et al. Precision and accuracy of an artificial anterior chamber system in obtaining corneal lenticules for lamellar keratoplasty. J Cataract Refract Surg. 2001;27(10):1679-87.

3. Springs CL, Joseph MA, Odom JV, Wiley LA. Predictability of donor lamellar graft diameter and thickness in an artificial anterior chamber system. Cornea. 2002;21(7):696-9.

4. Victor G,Faria e Sousa SJ,Alves MR, Nosé W. [MALKS: specifications and development]. Arq Bras Oftalmol. 2006;69(2):151-5. Portuguese.

5. Victor G, Sousa SJ,Alves MR, Nosé W. Evaluation of a new system for obtaining donor lamellar grafts. Cornea. 2007;26(2):151-3.

6. Pallikaris IG, Papatzanaki ME, Stathi EZ, Frenschock O, Georgiadis A. Laser in situ keratomileusis. Lasers Surg Med. 1990;10(5):463-8.

7. Buratto L, Ferrari M, Rama P. Excimer laser intrastromal keratomileusis. Am J Ophthalmol. 1992;113(3):291-5.

8. Azar DT, Jain S, Sambursky R, Strauss L. Microkeratome-assisted posterior keratoplasty. J Cataract Refract Surg. 2001;27(3):353-6.

9. Busin M,Zambianchi L, Arffa RC. Microkeratome-assisted lamellar keratoplasty for the surgical treatment of keratoconus. Ophthalmology. 2005;112(6):987-97.

10. Kang PC, McEntire MW, Thompson CJ, Moshirfar M. Preparation of donor lamellar tissue for deep lamellar endothelial keratoplasty using a microkeratome and artificial anterior chamber system: endothelial cell loss and predictability of lamellar thickness. Ophthalmic Surg Lasers Imaging. 2005;36(5):381-5.
11. Behrens A, Ellis K, Li L, Sweet PM, Chuck RS. Endothelial lamellar keratoplasty using an artificial anterior chamber and a microkeratome. Arch Ophthalmol. 2003;121(4):503-8.

12. Maguen E, Azen SP, Pinhas S, Villaseñor RA, Nesburn AB. Evaluation of sources of variation on the accuracy and reproducibility of microkeratome sections with the modified artificial anterior chamber. Ophthalmic Surg. 1982;13(3):217-20.

13. Thiel MA, Kaufmann C, Dedes W, Bochmann F, Becht CN, Schipper I Predictability of microkeratome-dependent flap thickness for DSAEK. Klin Monbl Augenheilkd. 2009;226(4):230-3.

14. Lubatschowski H. Overview of commercially available femtosecond lasers in refractive surgery. J Refract Surg. 2008;24(1):S102-7.

15. Santhiago MR, Wilson SE. Cellular effects after laser in situ keratomileusis flap formation with femtosecond lasers: a review. Cornea. 2012;31(2):198-205. Review.

16. Salomão MQ, Wilson SE. Femtosecond laser in laser in situ keratomileusis. J Cataract Refract Surg. 2010;36(6):1024-32. Review.

17. Ahn H, Kim JK, Kim CK, Han GH, Seo KY, Kim EK, et al. Comparison of laser in situ keratomileusis flaps created by 3 femtosecond lasers and a microkeratome. J Cataract Refract Surg. 2011;37(2):349-57.

18. de Medeiros FW, Kaur H, Agrawal V, Chaurasia SS, Hammel J, Dupps WJ Jr, et al. Effect of femtosecond laser energy level on corneal stromal cell death and inflammation. J Refract Surg. 2009;25(10):869-74.

19. Moshirfar M, Gardiner JP, Schliesser JA, Espandar L, Feiz V, Mifflin $\mathrm{MD}$, et al. Laser in situ keratomileusis flap complications using mechanical microkeratome versus femtosecond laser: retrospective comparison. J Cataract Refract Surg. 2010;36(11):1925-33.

20. Ziemer FEMTO LDV Operator manual. Document No. FL5910-0000046-32.

21. Bland JM,Altman DG. Measuring agreement in method comparison studies. Stat Methods Med Res. 1999;8(2):135-60. Review.

22. Rousseau A, Bensalem A, Garnier V, Savoldelli M, Saragoussi JJ, Renard G, et al. Interface quality of endothelial keratoplasty buttons obtained with optimised femtosecond laser settings. Br J Ophthalmol. 2012;96(1):122-7.

23. Mehta JS, Shilbayeh R, Por YM, Cajucom-Uy H, Beuerman RW, Tan DT.Femtosecond laser creation of donor cornea buttons for Descemetstripping endothelial keratoplasty. J Cataract Refract Surg. 2008;34(11):1970-5.

24. Weitkamp JW, Marsden HJ, Berke W, Daijo G. Agreement and repeatability of the Sonogage ultrasound pachometer compared with a Mitutoyo micrometer. Optom Vis Sci. 2008;85(5):359-63.

25. Jones YJ, Goins KM, Sutphin JE, Mullins R, Skeie JM. Comparison of the femtosecond laser (IntraLase) versus manual microkeratome (Moria ALTK) in dissection of the donor in endothelial keratoplasty: initial study in eye bank eyes. Cornea. 2008;27(1):88-93.

26. Suwan-Apichon O, Reyes JM, Griffin NB, Barker J, Gore P, Chuck RS. Microkeratome versus femtosecond laser predissection of corneal grafts for anterior and posterior lamellar keratoplasty. Cornea. 2006;25(8):966-8.

\section{Corresponding author: \\ Gustavo Victor}

República do Líbano Avenue, 1034

Zip code 04002-001 - São Paulo - (SP), Brazil

Phone: +55 (11) 3884-4020, Fax: +55 (11) 3884-7680

E-mail: gustavo.victor@eyeclinic.com.br

\section{ERRATA}

No artigo Victor G, Nosé W, Souza SJ, Pineda R, Alves MR. Analysis of low-energy and high-frequency femtosecond laser for the construction of deep anterior donor corneal lamellae. Rev Bras Oftalmol. 2014;73(2): 71-4, para afiliações leia-se:

Gustavo Victor ${ }^{1}$, Walton Nosé ${ }^{2}$, Sidney Julio de Faria e Sousa ${ }^{3}$, Roberto Pineda ${ }^{4}$, Milton Ruiz Alves ${ }^{1}$

${ }^{1}$ Department of Ophthalmology, Universidade de São Paulo, São Paulo, SP, Brazil;

2 Department of Ophthalmology, Universidade Federal de São Paulo, São Paulo, SP, Brazil;

${ }^{3}$ Department of Ophthalmology, Universidade de São Paulo, Ribeirão Preto, Ribeirão Preto, SP, Brazil;

${ }^{4}$ Department of Ophthalmology, Harvard Medical School, Boston, MA. EUA. 